\title{
A Rare Case of Primary Histiocytic Sarcoma of the Stomach
}

\author{
Nina Y. Petkova' ${ }^{\text {, Radka G. Hristoskova }}{ }^{2}$, Margarita L. Guenova ${ }^{3}$, Julian I. Raynov ${ }^{1}$ \\ ${ }^{1}$ Clinic of Hematology, Military Medical Academy, Sofia, Bulgaria \\ 2 Department of Pathology, Military Medical Academy, Sofia, Bulgaria \\ ${ }^{3}$ Laboratory of Hematopathology and Immunology, National Specialized Hospital for Active Treatment of Hematological Diseases, \\ Sofia, Bulgaria
}

\section{Correspondence:}

Nina Y. Petkova, Clinic of Hematology, Military Medical Academy, 3 St. Georgi Sofijski Str., 1606 Sofia, Bulgaria

E-mail:n.petkova@yahoo.com Tel: +359888 883183

Received: 11 May 2017

Accepted: 07 July 2017

Published Online: 31 Aug 2017

Published: 30 June 2018

Key words: histiocytic sarcoma, stomach, case report

Citation: Petkova NY, Hristoskova RG, Guenova ML, Raynov JI. A rare case of primary histiocytic sarcoma of the stomach. Folia Med (Plovdiv) 2018;60(2): 318-22.

doi: 10.1515/folmed-2017-0075
Histiocytic sarcoma is a rare lymphohematopoietic malignancy with aggressive clinical course and poor therapy response. The diagnosis relies on the confirmation of its histiocytic lineage and exclusion of other poorly differentiated tumors. Most of the cases present in extranodal sites, but primary gastric involvement is exceptional. We report a case of a 69-year-old woman with epigastric pain and systemic symptoms. Gastroscopy findings and biopsy report suggested a malignant neoplasm. The patient underwent distal subtotal gastrectomy with a 6-cm tumor in the body and antrum of the stomach and ten associated enlarged perigastric lymph nodes. Microscopically they were infiltrated with atypical tumor cells and immunohistochemical staining was positive for CD68, lysozyme, CD45, and CD4; $45 \%$ of the cells stained for $\mathrm{Ki}-67$. The pathologic diagnosis was histiocytic sarcoma. CT body scans showed only enlarged retroperitoneal and abdominal lymph nodes. The patient received six cycles of CHOEP chemotherapy with complete therapeutic response, but three months later she experienced an aggressive systemic sarcoma recurrence and although salvage chemotherapy was initiated she died of progressive disease. The presented case widens the differential diagnosis of gastric malignancies, and emphasizes the significance of immunohistochemical examination for histiocytic sarcoma diagnosis. The collection and evaluation of cases of gastric histiocytic sarcoma are important to obtain further progress in prognosis and treatment.

\section{INTRODUCTION}

Histiocytic sarcoma (HS) is an extremely rare lymphohematopoietic malignant neoplasm. Mathe et al. in $1970^{1}$ described a collection of malignant neoplastic cells with histologic features of large macrophages with abundant eosinophilic cytoplasm. He was the first to introduce the term histiocytic sarcoma for tumors with histologic similarities to macrophages previously referred to as reticulosarcoma and later as histiocytic lymphoma. World Health Organization defines HS as a malignant proliferation of cells that shows the morphologic and immunophenotypic features of mature tissue histiocytes. ${ }^{2}$ It accounts for less than $1 \%$ of hematologic malignancies ${ }^{2}$ and a limited number of cases have been reported in medical literature. Most patients are adults and male predilection is found in some studies. HS may occur in lymph nodes, but the majority of cases present in a variety of extranodal sites, most commonly gastrointestinal tract, skin and soft tissues; involvement of multiple sites is also known. ${ }^{2-5}$ Primary gastric involvement is exceptional and up to date only a small number of cases have been reported in the international medical literature.

\section{CASE REPORT}

We present a 69-year-old woman with a four-month history of progressive fatigue, weight loss, night swelling, intermittent fever, nausea and epigastric pain. She had chronic obstructive pulmonary disease with pulmonary hypertension, congestive heart failure and hypertension, but no history of previous known stomach disease. An ambulatory esophagogastroduodenoscopy revealed irregular lesions in the gastric cardia and corpus without obvious ulcer and the biopsy report suggested the presence of malignancy. Carcinoembryonic antigen, carbohydrate antigen 19-9, complete blood cell count, renal function and hepatic laboratory parameters were within normal ranges. The patient underwent distal subtotal gastrectomy with lymph node dissection. The resected specimen showed a 
tumor $6 \mathrm{~cm}$ in diameter in the body and antrum of the stomach. Ten associated enlarged perigastric lymph nodes were isolated along both curvatures and at the celiac plexus.

The histopathologic examination of the tumor showed infiltration in the gastric mucosa, submucosa and inner muscular layer of medium to large dyscohesive cells with polygonal shape of abundant and eosinophilic cytoplasm, eccentrically placed nuclei with distinguished nucleoli. Pleomorphic and multinucleated forms were also seen with a number of reactive cells including small lymphocytes, histiocytes and eosinophils, and an inflammation infiltrate (Fig. 1A). Enlarged perigastric lymph nodes were diffusely or partially involved with proliferation of the same polygonal cells, pleomorphic and multinucleated cells (Fig. 1B). The lesions were difficult to differentiate based on tissue morphology.

The additional immunohistochemical analysis demonstrated that the tumor cells were strongly reactive for CD68 (Fig. 2A), CD45, and lysozyme (Fig. 2B). CD4 immunostaining was also positive (Fig. 2C) and approximately 45\% of the tumor cells stained for Ki-67. They were negative for S-100 (Fig. 2D), and lack specific lymphoid (CD3, CD5, CD10, CD20, CD23, CD30), myeloid (myeloperoxidase), dendritic-cell (CD35) markers; pan-cytokeratin (AE1/AE3) monoclonal antibody was negative.

The histological and immunohistochemical diagnosis was HS of the stomach with lymph nodes involvement. One month after the operation the patient was referred to our clinic for further treatment.

On examination the patient's vital signs were normal, and she had no peripheral lymphadenopathy or hepatosplenomegaly. The laboratory tests showed: hemoglobin $113 \mathrm{~g} / \mathrm{L}$, leukocytes $8.47 \times 10^{9} / \mathrm{L}$, platelets $386 \times 10^{9} / \mathrm{L}, \beta 2$-microglobulin $4.44 \mathrm{mg} / \mathrm{L}$ and $\mathrm{LDH}$ 510 U/L. Bone marrow biopsy was normocellular with trilineage hematopoiesis and no evidence of involvement with HS or other hematologic neoplasm. Plain and contrast-enhanced CT body scans showed enlarged retroperitoneal, mesenteric and coeliac abdominal lymph nodes up to $3 \mathrm{~cm}$-diameter, some of them with central necrotic zone.

The patient received six cycles of CHOEP (cyclophosphamide, doxorubicin, vincristine, etoposide and prednisone) chemotherapy after surgery with a dose reduction of doxorubicin because of ejection fraction of $50 \%$. Control contrast-enhanced body CT was performed after four cycles and showed complete therapeutic response with no enlarged lymph nodes, she had no systemic symptoms. Three months after the last chemotherapy the patient presented with an aggressive systemic recurrence of the sarcoma with pulmonary lesions, enlarged abdominal and retroperitoneal lymph nodes, compressing the aorta and vena cava, and partial subrenal thrombosis of vena cava inferior. Although salvage chemotherapy was initiated the patient died due to multiple organ failure.

\section{DISCUSSION}

Histiocytic sarcoma of the stomach is extremely rare and only a small number of cases have been

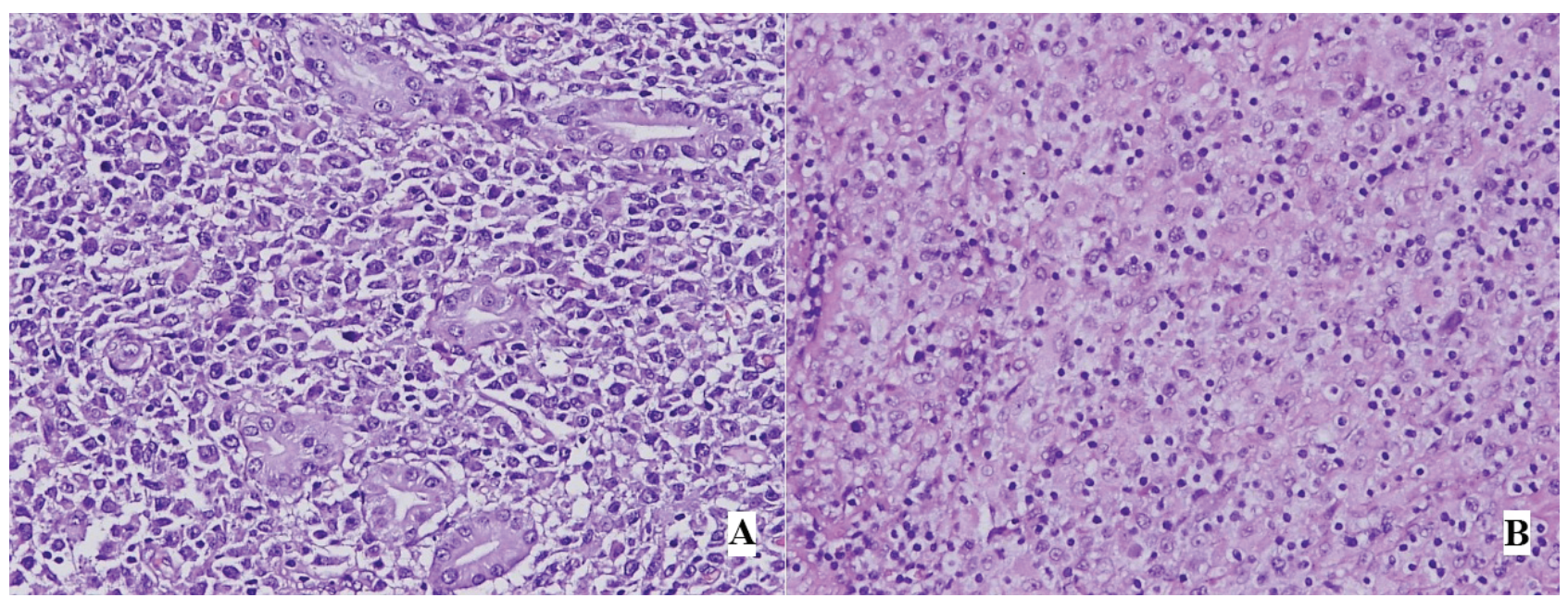

Figure 1. Gastric mucosa infiltrated by tumor cells, hematoxylin and eosin (A); Metastatic tumor cells in perigastric lymph nodes, hematoxylin and eosin (B). 


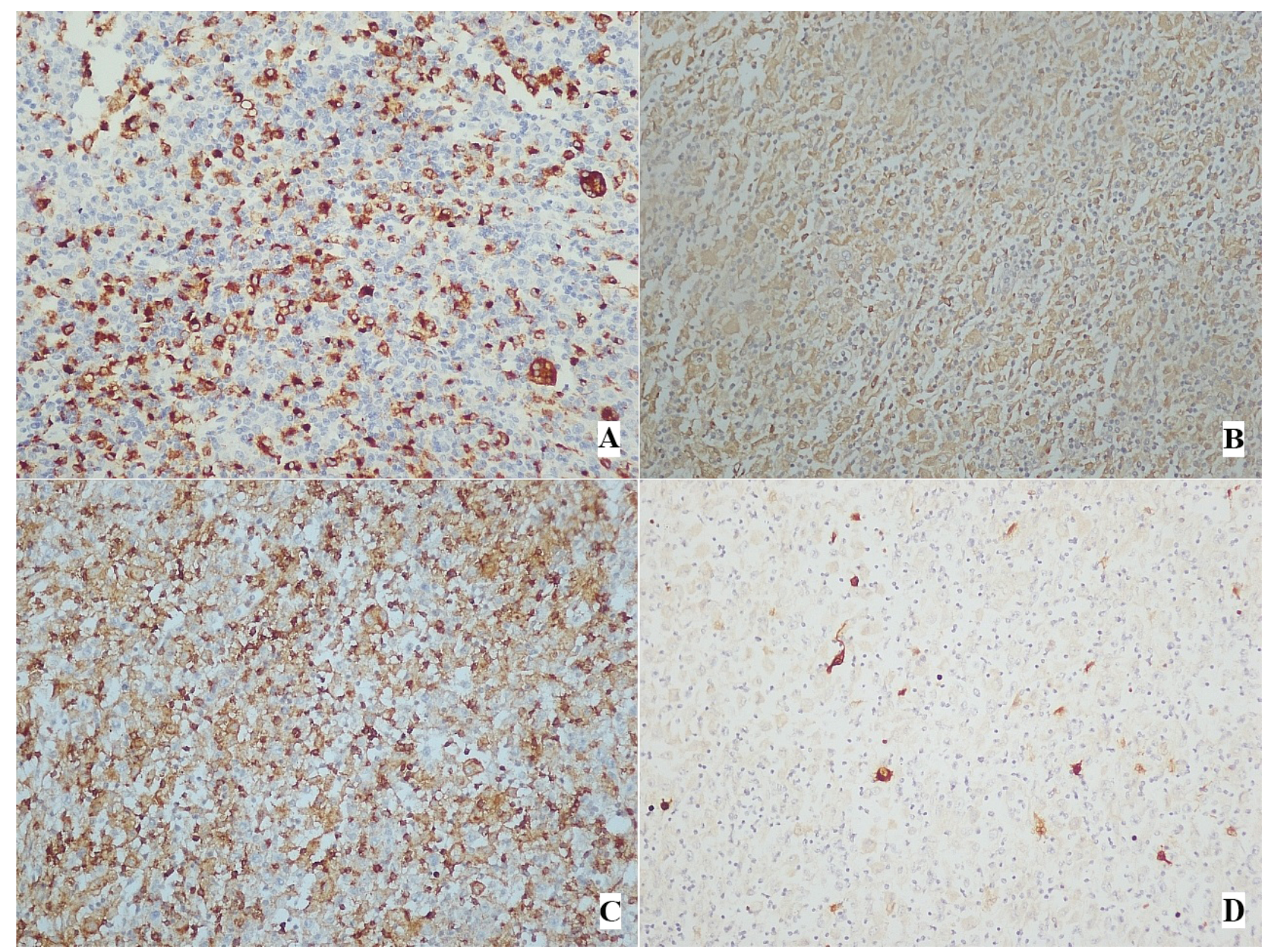

Figure 2. Immunohistochemical stains - tumor cells are positive for CD68 (A), Lysozyme (B), CD4 (C), and negative for S-100 (D).

described. Much of what is known about it is from an analysis of a systematic review of reported fourteen cases in medical literature. ${ }^{6}$ Gastric HS mostly occurred in middle age or elder with a mean of 57.9 years. ${ }^{6}$ Patients usually presented with a long time abdominal pain before diagnosis; the other major symptoms were melena, dyspeptic and systemic symptoms. ${ }^{6}$ HS showed no typical localization in the stomach. The tumor size in the cases described varied from $1.5 \mathrm{~cm}^{6}$ to $20 \mathrm{~cm} .{ }^{7}$ Lesions could be ulcerative with erosive hemorrhage. ${ }^{5,8}$ Regional lymph nodes involvement was found in half of reviewed cases. ${ }^{6}$ Gastric HS was described to involve multiple sites, including colon $^{3}$, jejunum ${ }^{5}$, esophagus $^{9}$, pancreas and liver. ${ }^{6,10}$

The imaging features of gastric HS are nonspecific and it is difficult to differentiate it from other gastric malignancies by radiological evaluation alone. ${ }^{8}$ There is no accepted staging, but HS is typically an FDG-avid neoplasm ${ }^{6,11}$ and staging relies on bone marrow biopsy and $\mathrm{CT}$ or PET/CT scans to look for multifocal disease.

Histopathology diagnosis is based on the neoplastic cells which are usually highly atypical, and malignant nature of the lesions is suggested based on the morphology, although specific diagnosis using only biopsy specimen is difficult. Cases arising primarily at extranodal sites may cause a diagnostic pathological dilemma, especially in the absense of a high degree of atypia or pleomorphism of the tumor cells masquerading as an inflammatory pseudotumor. ${ }^{11}$ The diagnosis of HS relies predominantly on the confirmation of its histiocytic lineage and the exclusion of other poorly differentiated tumors like lymphoma, carcinoma, sarcoma, and melanoma. ${ }^{3}$ HS is defined immunophenotypically by expression of one or more histiocytic marker (CD68, CD163, lysozyme) and absence of Langerhans cell (CD1a, langerin), follicular dendritic cell (CD21, CD35) and myeloid cell (CD33, CD13, myeloperoxidase) 
markers. CD45 and HLA-DR are usually positive and there may be expression of S-100 protein, but usually weak or focal. They are typically negative for specific B- and T-cell markers, CD4 is often positive, the $\mathrm{Ki}-67$ index is variable. ${ }^{2-4}$

Total or subtotal gastrectomy was the main treatment in reviewed cases of patients with gastric HS, rarely combined with chemotherapy ${ }^{6}$; half of them had regional lymph node metastases at the time of surgery. During follow up either local recurrence or distant metastasis were seen, and death due to the disease leaded to a survival time from 7 to 13 months, but the follow-up periods were relatively short, data was scarce and inconclusive. ${ }^{6}$ Two of the reported cases of gastric HS patients survived for a relative long time -18 months $^{12}$ and 3 years $^{5}$ after surgery and chemotherapy, suggesting that postoperative chemotherapy might be favorable. ${ }^{6}$

The patient we describe is a 69 -year-old woman, presenting with epigastric pain, nausea and constitutional symptoms which suggested an illness that affected the whole body. Gastroscopic examination with biopsy was the initial diagnostic work-up, but due to limited tissue, no further immunohistochemical testing was performed and adenocarcinoma could not be ruled out. Excisional biopsy is the preferred diagnostic method for HS and in our patient distal subtotal gastrectomy was diagnostic and therapeutic approach. Lymph node metastases were found during the operation and body CT scans confirmed enlarged abdominal lymph nodes during staging.

In our case the deeply infiltrative growth of the tumor in the gastric wall and the presence of lymph node metastases indicated the malignant and aggressive nature of this tumor. The morphology was of a poorly differentiated malignant neoplasm. CD68 positivity confirmed histiocytic derivation of the tumor cells and the absence of S-100 was consistent with mature histiocytes rather than Langerhans cells. Ki-67 positivity of $45 \%$ of the tumor cells indicated higher cell proliferation. Immunohistochemical staining excluded myeloid neoplasm, lymphoma, carcinoma, sarcoma, and melanoma.

Unfortunately, survival of our patient was less than 1 years -10 months after diagnosis due to the aggressive nature of the tumor and initially poor prognosis, because of the tumor size and the disseminated disease. Therapeutic options were limited by the patient's age and comorbidities.

Histiocytic sarcoma is usually an aggressive neoplasm with grim clinical course and poor re- sponse to therapy, although exceptions have been reported. Tumor size and stage are believed to be important prognostic factors. ${ }^{2-4,13}$ There are no accepted treatment guidelines for HS due to the rarity of the disease. The majority of the patients with HS present with systemic disease at diagnosis and outcomes for treating metastatic HS with surgery, chemotherapy, or radiotherapy are unsatisfactory. Treatments with monoclonal antibodies, immunomodulators and novel targeted agents are also reported in patients with HS. The prognosis, however, remains generally poor.

\section{CONCLUSION}

To the best of our knowledge, this is the first case of histiocytic sarcoma of the stomach described in Bulgaria. It widens the differential diagnosis of gastric malignancies, and underlines the significance of immunohistochemical examination for HS diagnosis. Since gastric HS is a rare disease the collection and evaluation of additional cases are important to obtain further progress in prognosis and guide treatment decisions.

\section{REFERENCES}

1. Mathé G, Gerard-Marchant R, Texier J, et al. The two varieties of lymphoid tissue "reticulosarcomas", histiocytic and histioblastic types. Br J Cancer 1970; 24:687-95.

2. Grogan T, Pileri S, Chan J, et al. Histiocytic sarcoma. In: Swerdlow S, Campo E, Harris N, et al. WHO Classification of Tumours of Haematopoeitic and Lymphoied Tissues. IARC, Lyon, 2008: 356-7.

3. Hornick J, Jaffe E, Fletcher C. Extranodal histiocytic sarcoma: clinicopathologic analysis of 14 cases of a rare epithelioid malignancy. Am J Surg Pathol 2004;28 (9):1133-44.

4. Vos J, Abbondanzo S, Barekman C, et al. Histiocytic sarcoma: a study of five cases including the histiocyte marker CD163. Mod Pathol 2005;18:693-704.

5. Sundersingh S, Majhi U, Seshadhri R, et al. Multifocal histiocytic sarcoma of the gastrointestinal tract. Indian J Pathol Microbiol 2012;55(2):233-5.

6. Yang Y, Jin L, Zhang J, et al. Primary huge histiocytic sarcoma of the stomach: a case report and systematic review. Int J Clin Exp Med 2016;9(10):19785-90.

7. Congyang L, Xinggui W, Hao L, et al. Synchronous histiocytic sarcoma and diffuse large B cell lymphoma involving the stomach: a case report and review of the literature. Int J Hematol 2011;93:247-52.

8. Shen X, Liu F, Ni R, et al. Primary histiocytic sarcoma of the stomach: a case report with imaging findings. World J Gastroenterol 2013;19: 422-5. 
9. Pakravan A, Bhatia R, Oshima K, et al. Histiocytic sarcoma: the first reported case of primary esophageal involvement. Am J Gastroenterol 2014;109: 291-2.

10. Hanaoka T, Jingu K, Tochigi T, et al. A case of gcsf-producing histiocytic sarcoma of the stomach. Int Surg 2015;100:568-73.

11. Lee D, Kim Y, Chung S, et al. Primary gastric histiocytic sarcoma reminiscent of inflammatory pseudotumor: a case report with review of the literature.
Korean J Pathol 2014;48:258-62.

12. Alvaro T, Bosch R, Salvado M, et al. True histiocytic lymphoma of the stomach associated with low-grade B-cell mucosa-associated lymphoid tissue (MALT)type lymphoma. Am J Surg Pathol 1996; 20:1406-11.

13. Dalia S, Jaglal M, Chervenick P, et al. Clinicopathologic characteristics and outcomes of histiocytic and dendritic cell neoplasms: the moffitt cancer center experience over the last twenty five years. Cancers (Basel) 2014;6(4):2275-95.

\title{
Редкий вид первичной гистиоцитарной саркомы желудка
}

\author{
Нина Й. Петкова ${ }^{1}$, Радка Г. Христоскова ${ }^{2}$, Маргарита Л. Генова ${ }^{3}$, Юлиан И. Райнов ${ }^{1}$ \\ ${ }^{1}$ Клиника гематологии, Военно-медицинская академия, София, Болгария \\ 2 Кафедра патологии, Военно-медицинская академия, София, Болгария \\ 3 Лаборатория гемопатологии и иммунологии, Национальная специализированная больница активного лечения гема- \\ тологических заболеваний, София, Болгария
}

\begin{abstract}
Адрес для корреспонденции: Нина Й. Петкова, Клиника гематологии, Военно-

медицинская академия, ул.„Св. Георги Софийски" 3, София, 1606, Болгария

E-mail:n.petkova@yahoo.com

Tel: +359888 883183
\end{abstract}

Дата получения: 11 мая 2017 Дата приемки: 07 июля 2017 Дата онлайн публикации: 31 августа 2017

Дата публикации: 30 июня 2018

\section{Ключевые слова:}

гистиоцитарная саркома, желудок, клинический случай

Образец цитирования: Petkova NY, Hristoskova RG, Guenova ML, Raynov Jl. A rare case of primary histiocytic sarcoma of the stomach. Folia Med (Plovdiv) 2018;60(2): 318-22.

doi: 10.1515/folmed-2017-0075
Гистиоцитарная саркома является редким видом злокачественной опухоли лимфатической и кроветворной систем, которая характеризуется агрессивным клиническим течением и плохим ответом на лечение. Диагноз ставится на основании подтверждения гистиоцитарного происхождения и отрицания возможности других слабо дифференцированных опухолей. В большинстве случаев у больных проявляется экстранодальное распространение, но первичное вовлечение желудка встречается в редких случаях. Нами представлен клинический случай больной в возрасте 69 лет с проявлением эпигастральной боли и системными симптомами. Находка при гастроскопии и результаты биопсии свидетельствуют о злокачественном новообразовании. Больной была произведена дистальная субтотальная гастрэктомия 6 сантиметровой опухоли в теле и полости желудка и десяти связанных увеличенных перигастральных лимфатических узлов. Микроскопически они были инфильтрированы атипичными опухолевыми клетками, а иммуногистохимическое окрашивание показало положительный результат в отношении CD68, лизозима, CD45, CD4; 45\% из клеток окрашиваются на наличие Кі-67. Поставлен патологический диагноз - гистиоцитарная саркома. Компьютерная томография установила лишь увеличенные ретроперитониальные и абдоминальные лимфатические узлы. Больной было проведено шесть сеансов химиотерапии по схеме CHOEP с полным терапевтическим ответом, но по истечении трёх месяцев установлен агрессивный системный рецидив саркомы и вопреки предпринятой спасительной химиотерапии наступила смерть в результате прогрессивного заболевания. Представленный случай расширяет дифференциальный диагноз желудочных злокачественных опухолей и подчёркивает значение иммуногистохимического исследования при диагнозе гистиоцитарной саркомы. Сбор информации о случаях гистиоцитарной саркомы и их анализ являются действительно важными для развития новых методов в области прогноза и лечения данного заболевания 